\title{
An Optimized Method to Isolate Human Fibroblasts from Tissue for ex vivo Analysis
}

Sara Waise ${ }^{1}$, Rachel Parker ${ }^{1}$, Matthew J. J. Rose-Zerilli ${ }^{1}$, David M. Layfield ${ }^{1}$, Oliver Wood ${ }^{1}$, Jonathan West $^{1,2}$, Christian H. Ottensmeier ${ }^{1,3}$, Gareth J. Thomas ${ }^{1, *}$ and Christopher J. Hanley ${ }^{1, \#, *}$

${ }^{1}$ Cancer Sciences Unit, University of Southampton, UK; ${ }^{2}$ Institute for Life Sciences, University of Southampton, UK; ${ }^{3}$ Cancer Research UK and NIHR Southampton Experimental Cancer Medicine Centre, UK

*For correspondence: C.J.Hanley@soton.ac.uk

\#Contributed equally to this work

[Abstract] Despite their involvement in many physiological and pathological processes, fibroblasts remain a poorly-characterized cell type. Analysis of primary fibroblasts while maintaining their in vivo phenotype is challenging: standard methods for fibroblast isolation require cell culture in vitro, which is known to alter phenotypes. Previously-described protocols for the dissociation of primary tissues fail to extract sufficient numbers of fibroblasts, instead largely yielding immune cells. Here, we describe an optimized method for generating a fibroblast-enriched single-cell suspension from human tissues using combined mechanical and enzymatic dissociation. This allows analysis of ex vivo fibroblasts without the need for culture in vitro.

Keywords: Tissue disaggregation, Stroma, Fibroblasts, Lung

[Background] Fibroblasts are almost ubiquitous in human tissues, and the most common cell type in the stroma of a number of solid tumours, where they are referred to as cancer-associated fibroblasts (CAFs) (Kalluri and Zeisberg, 2006; Servais and Erez, 2013; Rupp et al., 2014; Ishii et al., 2016). CAFs are associated with multiple hallmarks of malignancy (Ishii et al., 2016; Tao et al., 2017) and correlate with poor prognosis in multiple solid tumors (Hanley et al., 2018).

Given these tumor-promoting effects, and their genetic stability relative to cancer cells (Ishii et al., 2016), it is unsurprising that fibroblasts are an attractive therapeutic target. However, clinical trials targeting CAFs have so far yielded disappointing results (Hofheinz et al., 2003; Narra et al., 2007). This may, in part, be due to variation within the fibroblast population: these cells are known to be heterogeneous in both normal and disease states (Desmoulière et al., 2004; Sugimoto et al., 2006; Anderberg and Pietras, 2009; Servais and Erez, 2013; Witowski et al., 2015; Kalluri, 2016; Mellone et al., 2017). However, this heterogeneity remains poorly-characterized and it is not yet clear how many subtypes are present within a given tissue or tumor type, or the nature of functional differences between groups (Herrera et al., 2013; Servais and Erez, 2013; Ishii et al., 2016).

Characterizing heterogeneity of cell populations within human tissues often requires analysis at a single-cell level. Single-cell RNA sequencing is a valuable platform for characterizing multicellular ecosystems. However, fibroblasts are embedded within extracellular matrix and are particularly difficult to isolate: this has led to under-representation in, for example, single-cell RNA sequencing datasets 
(Lambrechts et al., 2018). Unlike many murine models, there is no standardized disaggregation protocol for human solid tissues. A number of different immune cell populations have been successfully isolated and analyzed directly from tissues (Holt et al., 1986; Perrot et al., 2007; Grange et al., 2011; Quatromoni et al., 2015; Ganesan et al., 2017). However, epithelial and non-immune stromal cells are usually cultured in vitro prior to analysis (Lurton et al., 1999; Koumas et al., 2003; Comhair et al., 2012; Barkauskas et al., 2013; Mackay et al., 2013). Culture in vitro has been shown to change fibroblast phenotypes (Öhlund et al., 2017; Waise et al., 2019); thus, how and whether the functional differences described in vitro are maintained in vivo is not yet known (Lurton et al., 1999).

Here, we describe an optimized protocol for the isolation of fibroblasts from primary human tissues, allowing immediate analysis without the need for culture in vitro. In brief, primary samples undergo mechanical and enzymatic dissociation, followed by incubation with TrypLE and red cell lysis buffer (to disrupt intercellular adhesions and remove red blood cells, respectively). Use of this approach yields a single-cell suspension consisting of multiple cell types, with approximately a 4-fold greater proportion of fibroblasts compared to other disaggregation strategies (Waise et al., 2019). We describe use of this protocol for the ex vivo analysis of fibroblasts in both normal and disease states using single-cell RNA sequencing, and highlight alternative downstream applications. In addition, this approach may have applications in the analysis of other cell types (e.g., epithelial cells).

\section{Materials and Reagents}

1. $5 \mathrm{ml}$ syringes (BD Plastipak, catalog number: 307731 )

2. $10 \mathrm{ml}$ syringes (BD Plastipak, catalog number: 307736 )

3. Pasteur pipette (Scientific Laboratory Supplies, catalog number: PIP4210)

4. $50 \mathrm{ml}$ Falcon tube (Sarstedt, Brand, model/catalog number: $114 \times 28 \mathrm{~mm}, 62.547 .004$ )

5. $15 \mathrm{ml}$ Falcon tube (Sarstedt, Brand, model/catalog number: $120 \times 17 \mathrm{~mm}, 62.554 .002$ )

6. Sterile scalpel \#21 blade (Swann-Morton, catalog number: 0507)

7. Polystyrene cell culture dish (Sarstedt, catalog number: 83.3902)

8. Syringe filtration unit Filtropur S 0.2 (Sarstedt, catalog number: 83.1826.001)

9. Scissors

10. Collagenase $P$ from Clostridium histolyticum (Merck, Roche, catalog number: 11213857001). Reconstitute in PBS to $150 \mathrm{U} / \mathrm{ml}$, store $100 \mu$ laliquots at $-20^{\circ} \mathrm{C}$

11. TrypLE Express Enzyme (no phenol red; Thermo Fisher, catalog number: 12604013). Store at room temperature protected from light for up to 2 years

12. Fetal bovine serum (Biosera, catalog number: FB-1001/500). Store at $-20^{\circ} \mathrm{C}$ for up to 60 months

13. Deoxyribonuclease I from bovine pancreas (Merck, Sigma-Aldrich, catalog number: D4263). Reconstitute in $1 \mathrm{ml}$ PBS $(2000 \mathrm{U} / \mathrm{ml})$, store $40 \mu \mathrm{l}$ aliquots at $-20^{\circ} \mathrm{C}$

14. Dulbecco's Modified Eagle Medium (Merck, Sigma-Aldrich, catalog number: D5671-500ML). Store at $4{ }^{\circ} \mathrm{C}$

15. L-glutamine (Merck, Sigma-Aldrich, catalog number: G7513-100ML). Store at $-20^{\circ} \mathrm{C}$ for up to 2 
years

16. Penicillin-streptomycin (Merck, Sigma-Aldrich, catalog number: P4333-100ML). Store at $-20^{\circ} \mathrm{C}$ for up to 2 years

17. Phosphate-buffered saline (PBS)

18. Amphotericin B (250 $\mu \mathrm{g} / \mathrm{ml}$; Gibco, catalog number: $15290-018)$. Store at $-20^{\circ} \mathrm{C}$ for 1 year

19. Sterile double-distilled $\mathrm{H}_{2} \mathrm{O}$

20. Red blood cell lysis buffer (10x; BioLegend, catalog number: 420301). Store at $4{ }^{\circ} \mathrm{C}$

21. DNase stock solutions

22. "Complete" DMEM (see Recipes)

23. "Empty" DMEM (see Recipes)

\section{Equipment}

1. Orbital shaker-incubator (e.g., Grant-bio Orbital Shaker-Incubator ES-20)

2. EASYStrainer $40 \mu \mathrm{m}$ (Grener Bio-One, catalog number: 542040)

3. Centrifuge

\section{Procedure}

A. Tissue dissociation

1. Sample collection

Transport the tissue sample in "empty" DMEM (Recipe 2) on ice.

2. Prepare working solutions

a. In a $50 \mathrm{ml}$ Falcon tube, add $100 \mu \mathrm{l}$ Collagenase $\mathrm{P}$ and $40 \mu \mathrm{l}$ DNase stock solutions to $5 \mathrm{ml}$ "complete" DMEM (Recipe 1).

b. Make PBS-A: add $1 \mu \mathrm{l}$ Amphotericin to $10 \mathrm{ml}$ PBS in a $15 \mathrm{ml}$ Falcon tube.

3. Mechanical dissociation

In a polystyrene Petri dish, incise the tissue 10-12 times to relax the tissue.

4. Wash sample in PBS-A

a. Add $5 \mathrm{ml} \mathrm{PBS-A}$ to incised tissue, leave at room temperature for $5 \mathrm{~min}$.

b. This process may be repeated if the sample is particularly congested.

5. Enzymatic dissociation

a. Using scissors, cut the Pasteur pipette bulb at a 45-degree angle to create a scoop. Use this to remove the tissue from the PBS-A.

b. Transfer to the $50 \mathrm{ml}$ Falcon tube containing the Collagenase P/DNase solution.

c. Transfer the $50 \mathrm{ml}$ Falcon tube to the orbital shaker.

d. Incubate at $37^{\circ} \mathrm{C}$ with agitation (200 rpm) for $15 \mathrm{~min}$.

e. After $15 \mathrm{~min}$, remove from the orbital shaker and sequentially pipette with $50 \mathrm{ml}, 10 \mathrm{ml}$ and $5 \mathrm{ml}$ pipette tips to promote dissociation. 
f. Return to the orbital shaker for a further $15 \mathrm{~min}$, then repeat sequential pipetting.

g. Return to the orbital shaker for a further $30 \mathrm{~min}$, then repeat sequential pipetting.

6. TrypLE treatment
a. Centrifuge the sample at $450 \times g$ for $5 \mathrm{~min}$.
b. Remove the supernatant and re-suspend the resulting pellet in $1 \mathrm{ml}$ of undiluted TrypLE.
c. Incubate at $37^{\circ} \mathrm{C}$ for $10 \mathrm{~min}$.

7. Removing non-digested tissue fragments
a. Add tissue strainer to a new $50 \mathrm{ml}$ Falcon tube on ice.
b. Strain tissue/enzyme suspension, pressing through with plunger of $5 \mathrm{ml}$ syringe, simultaneously washing with "empty" DMEM.
c. Keep the sample on ice from this point.

8. Red blood cell lysis
a. Centrifuge the sample at $450 \times g$ for $5 \mathrm{~min}$ at $4{ }^{\circ} \mathrm{C}$.
b. Aspirate the medium.
c. Re-suspend the pellet in $1 \mathrm{ml}$ red blood cell lysis solution.
d. Incubate at $4{ }^{\circ} \mathrm{C}$ for $10 \mathrm{~min}$.
e. Centrifuge at $450 \times g$ for $5 \mathrm{~min}$ at $4{ }^{\circ} \mathrm{C}$.

9. Sample collection
a. Aspirate the red cell lysis buffer.
b. Re-suspend the pellet in $1 \mathrm{ml}$ of "complete" DMEM.
c. The cells are now ready for quantification (if necessary) and use.

\section{$\underline{\text { Notes }}$}

1. The single-cell suspension may be used for a number of downstream applications, including single-cell RNA sequencing, establishing primary fibroblast cultures, and isolating fibroblast subpopulations. For single-cell RNA sequencing with the Drop-seq platform, re-suspend the cells in double-distilled $\mathrm{H}_{2} \mathrm{O}$ supplemented with $9 \%$ Optiprep (Sigma-Aldrich), $1 \%$ PBS and $0.1 \%$ BSA, and perform as per Macosko et al. (2015) with the following modifications: 500 ng cDNA for PCR, 15 PCR cycles. The number of cells it is feasible to use will depend on the yield from the microfluidic step.

2. To establish primary cell cultures, plate $1 \times 10^{5}$ cells $/ \mathrm{cm}^{2}$ to tissue culture plates in 'Complete' DMEM. Incubate in a humidified incubator at $37^{\circ} \mathrm{C}$ and $5 \% \mathrm{CO}_{2}$ for $2 \mathrm{~h}$ to allow cells to adhere, before washing three times with PBS to remove non-adherent cells. This typically yields a $99.1 \%$ pure fibroblast $\left(\mathrm{CD} 45-\mathrm{EpCAM}-\mathrm{CD} 31-\mathrm{CD} 90^{+}\right)$culture, as determined by flow cytometry analysis. However, users should note that these culture conditions will not maintain in vivo fibroblast phenotypes (Waise et al., 2019).

3. Antibodies directed to specific fibroblast surface markers (e.g., PDGFR- $\alpha$ [Erez et al., 2010]), in combination with fluorescence-activated or magnetic cell sorting, can be used for isolation of 
fibroblast subpopulations. It is of note when employing these methods that enzymatic disaggregation can alter surface marker expression (Gray et al., 2002; Grange et al., 2011; Quatromoni et al., 2015), and that no single surface marker will reliably identify or differentiate all fibroblast populations (Sugimoto et al., 2006; Lambrechts et al., 2018).

\section{$\underline{\text { Recipes }}$}

1. "Complete" DMEM

Dulbecco's Modified Eagle Medium (Sigma-Aldrich)

$10 \%(\mathrm{v} / \mathrm{v})$ fetal calf serum (Biosera)

$1 \%(\mathrm{v} / \mathrm{v})$ L-glutamine (Sigma-Aldrich)

$1 \%(\mathrm{v} / \mathrm{v})$ penicillin-streptomycin (Sigma-Aldrich)

2. "Empty" DMEM

Dulbecco's Modified Eagle Medium (Sigma-Aldrich) only

\section{Acknowledgments}

This protocol was derived from previously-published data ${ }^{28}$. This work was supported by Cancer Research UK and Medical Research Council Clinical Research Training Fellowships and a Pathological Society Trainee's Small Grant to SW. Implementation of Drop-seq was supported by a Medical Research Council Discovery award (MC_PC_15078) and a Southampton Cancer Research UK Centre Development Fund Award to MJJRZ, CHO, JW, CJH \& GJT. RP was supported by a John Goldman Fellowship for Future Science (2016/JGF/0003; Leuka Charity) awarded to MJJRZ. The authors thank Evan Macosko, Melissa Goldman and Steve McCarroll for their helpful advice, Dr. Serena Chee (University Hospital Southampton), Benjamin Johnson, Carine Fixmer and Maria Lane (TargetLung Clinical Trials Associates) for enabling access to clinical samples, and the patients involved in this study.

\section{Competing interests}

The authors declare no competing interests.

\section{Ethics}

Lung samples were received fresh from patients undergoing surgery at Southampton General Hospital (TargetLung study; approved by NRES Committee South Central: Hampshire A, REC number 14/SC/0186). All research was performed in accordance with the appropriate regulations. Informed consent was obtained from patients or their legal guardians. 


\section{$\underline{\text { References }}$}

1. Anderberg, C. and Pietras, K. (2009). On the origin of cancer-associated fibroblasts. Cell Cycle 8(10): 1461-1462.

2. Barkauskas, C. E., Cronce, M. J., Rackley, C. R., Bowie, E. J., Keene, D. R., Stripp, B. R., Randell, S. H., Noble, P. W. and Hogan, B. L. (2013). Type 2 alveolar cells are stem cells in adult lung. $J$ Clin Invest 123(7): 3025-3036.

3. Comhair, S. A., Xu, W., Mavrakis, L., Aldred, M. A., Asosingh, K. and Erzurum, S. C. (2012). Human primary lung endothelial cells in culture. Am J Respir Cell Mol Biol 46(6): 723-730.

4. Desmouliere, A., Guyot, C. and Gabbiani, G. (2004). The stroma reaction myofibroblast: a key player in the control of tumor cell behavior. Int J Dev Biol 48(5-6): 509-517.

5. Erez, N., Truitt, M., Olson, P., Arron, S. T. and Hanahan, D. (2010). Cancer-associated fibroblasts are activated in incipient neoplasia to orchestrate tumor-promoting inflammation in an NF-kappaB-Dependent manner. Cancer Cell 17(2): 135-147.

6. Ganesan, A. P., Clarke, J., Wood, O., Garrido-Martin, E. M., Chee, S. J., Mellows, T., Samaniego-Castruita, D., Singh, D., Seumois, G., Alzetani, A., Woo, E., Friedmann, P. S., King, E. V., Thomas, G. J., Sanchez-Elsner, T., Vijayanand, P. and Ottensmeier, C. H. (2017). Tissueresident memory features are linked to the magnitude of cytotoxic $T$ cell responses in human lung cancer. Nat Immunol 18(8): 940-950.

7. Gray, D. H., Chidgey, A. P. and Boyd, R. L. (2002). Analysis of thymic stromal cell populations using flow cytometry. $J$ Immunol Methods 260(1-2): 15-28.

8. Grange, C., Letourneau, J., Forget, M. A., Godin-Ethier, J., Martin, J., Liberman, M., Latour, M., Widmer, H., Lattouf, J. B., Piccirillo, C. A., Cailhier, J. F. and Lapointe, R. (2011). Phenotypic characterization and functional analysis of human tumor immune infiltration after mechanical and enzymatic disaggregation. J Immunol Methods 372(1-2): 119-126.

9. Hanley, C. J., Mellone, M., Ford, K., Thirdborough, S. M., Mellows, T., Frampton, S. J., Smith, D. M., Harden, E., Szyndralewiez, C., Bullock, M., Noble, F., Moutasim, K. A., King, E. V., Vijayanand, P., Mirnezami, A. H., Underwood, T. J., Ottensmeier, C. H. and Thomas, G. J. (2018). Targeting the myofibroblastic cancer-associated fibroblast phenotype through inhibition of NOX4. J Natl Cancer Inst 110(1).

10. Herrera, M., Islam, A. B., Herrera, A., Martin, P., Garcia, V., Silva, J., Garcia, J. M., Salas, C., Casal, I., de Herreros, A. G., Bonilla, F. and Pena, C. (2013). Functional heterogeneity of cancerassociated fibroblasts from human colon tumors shows specific prognostic gene expression signature. Clin Cancer Res 19: 5914-5926.

11. Hofheinz, R. D., al-Batran, S. E., Hartmann, F., Hartung, G., Jager, D., Renner, C., Tanswell, P., Kunz, U., Amelsberg, A., Kuthan, H. and Stehle, G. (2003). Stromal antigen targeting by a humanised monoclonal antibody: an early phase II trial of sibrotuzumab in patients with metastatic colorectal cancer. Onkologie 26(1): 44-48. 
Please cite this article as: Waise et. al., (2019). An Optimized Method to Isolate Human Fibroblasts from Tissue for ex vivo Analysis,Bio-protocol 9 (23):

12. Holt, P. G., Robinson, B. W., Reid, M., Kees, U. R., Warton, A., Dawson, V. H., Rose, A., SchonHegrad, M. and Papadimitriou, J. M. (1986). Extraction of immune and inflammatory cells from human lung parenchyma: evaluation of an enzymatic digestion procedure. Clin Exp Immunol 66(1): 188-200.

13. Ishii, G., Ochiai, A. and Neri, S. (2016). Phenotypic and functional heterogeneity of cancerassociated fibroblast within the tumor microenvironment. Adv Drug DelivRev 99(Pt B): 186-196.

14. Kalluri, R. (2016). The biology and function of fibroblasts in cancer. Nat Rev Cancer 16(9): 582598.

15. Kalluri, R. and Zeisberg, M. (2006). Fibroblasts in cancer. Nat Rev Cancer 6(5): 392-401.

16. Koumas, L., Smith, T. J., Feldon, S., Blumberg, N. and Phipps, R. P. (2003). Thy-1 expression in human fibroblast subsets defines myofibroblastic or lipofibroblastic phenotypes. Am J Pathol 163(4): 1291-1300.

17. Lambrechts, D., Wauters, E., Boeckx, B., Aibar, S., Nittner, D., Burton, O., Bassez, A., Decaluwe, H., Pircher, A., Van den Eynde, K., Weynand, B., Verbeken, E., De Leyn, P., Liston, A., Vansteenkiste, J., Carmeliet, P., Aerts, S. and Thienpont, B. (2018). Phenotype molding of stromal cells in the lung tumor microenvironment. Nat Med 24(8): 1277-1289.

18. Lurton, J., Rose, T. M., Raghu, G. and Narayanan, A. S. (1999). Isolation of a gene product expressed by a subpopulation of human lung fibroblasts by differential display. Am J Respir Cell Mol Biol 20(2): 327-331.

19. Mackay, L. S., Dodd, S., Dougall, I. G., Tomlinson, W., Lordan, J., Fisher, A. J. and Corris, P. A. (2013). Isolation and characterisation of human pulmonary microvascular endothelial cells from patients with severe emphysema. Respir Res 14: 23.

20. Macosko, E. Z., Basu, A., Satija, R., Nemesh, J., Shekhar, K., Goldman, M., Tirosh, I., Bialas, A. R., Kamitaki, N., Martersteck, E. M., Trombetta, J. J., Weitz, D. A., Sanes, J. R., Shalek, A. K., Regev, A. and McCarroll, S. A. (2015). Highly parallel genome-wide expression profiling of individual cells using nanoliter droplets. Cell 161(5): 1202-1214.

21. Mellone, M., Hanley, C. J., Thirdborough, S., Mellows, T., Garcia, E., Woo, J., Tod, J., Frampton, S., Jenei, V., Moutasim, K. A., Kabir, T. D., Brennan, P. A., Venturi, G., Ford, K., Herranz, N., Lim, K. P., Clarke, J., Lambert, D. W., Prime, S. S., Underwood, T. J., Vijayanand, P., Eliceiri, K. W., Woelk, C., King, E. V., Gil, J., Ottensmeier, C. H. and Thomas, G. J. (2017).Induction of fibroblast senescence generates a non-fibrogenic myofibroblast phenotype that differentially impacts on cancer prognosis. Aging (Albany NY) 9(1): 114-132.

22. Narra, K., Mullins, S. R., Lee, H. O., Strzemkowski-Brun, B., Magalong, K., Christiansen, V. J., McKee, P. A., Egleston, B., Cohen, S. J., Weiner, L. M., Meropol, N. J. and Cheng, J. D. (2007). Phase II trial of single agent Val-boroPro (Talabostat) inhibiting Fibroblast Activation Protein in patients with metastatic colorectal cancer. Cancer Biol Ther 6(11): 1691-1699.

23. Ohlund, D., Handly-Santana, A., Biffi, G., Elyada, E., Almeida, A. S., Ponz-Sarvise, M., Corbo, V., Oni, T. E., Hearn, S. A., Lee, E. J., Chio, II, Hwang, C. I., Tiriac, H., Baker, L. A., Engle, D. D., Feig, C., Kultti, A., Egeblad, M., Fearon, D. T., Crawford, J. M., Clevers, H., Park, Y. and 
Please cite this article as: Waise et. al., (2019). An Optimized Method to Isolate Human Fibroblasts from Tissue for ex vivo Analysis,Bio-protocol 9 (23):

Tuveson, D. A. (2017). Distinct populations of inflammatory fibroblasts and myofibroblasts in pancreatic cancer. J Exp Med 214(3): 579-596.

24. Perrot, I., Blanchard, D., Freymond, N., Isaac, S., Guibert, B., Pacheco, Y. and Lebecque, S. (2007). Dendritic cells infiltrating human non-small cell lung cancer are blocked at immature stage. $J$ Immunol, 178(5): 2763-2769.

25. Quatromoni, J. G., Singhal, S., Bhojnagarwala, P., Hancock, W. W., Albelda, S. M. and Eruslanov, E. 2015. An optimized disaggregation method for human lung tumors that preserves the phenotype and function of the immune cells. J Leukoc Biol 97(1): 201-209.

26. Rupp, C., Scherzer, M., Rudisch, A., Unger, C., Haslinger, C., Schweifer, N., Artaker, M., Nivarthi, H., Moriggl, R., Hengstschläger, M., Kerjaschki, D., Sommergruber, W., Dolznig, H. and GarinChesa, P. (2014).IGFBP7, a novel tumor stroma marker, with growth-promoting effects in colon cancer through a paracrine tumor-stroma interaction. Oncogene, 34(7): 815-825.

27. Servais, C. and Erez, N. (2013). From sentinel cells to inflammatory culprits: cancer-associated fibroblasts in tumour-related inflammation. J Pathol 229(2): 198-207.

28. Sugimoto, H., Mundel, T. M., Kieran, M. W. and Kalluri, R. (2006). Identification of fibroblast heterogeneity in the tumor microenvironment. Cancer Biol Ther 5(12): 1640-1646.

29. Tao, L., Huang, G., Song, H., Chen, Y. and Chen, L. (2017). Cancer associated fibroblasts: An essential role in the tumor microenvironment. Oncol Lett 14(3): 2611-2620.

30. Waise, S., Parker, R., Rose-Zerilli, M. J. J., Layfield, D. M., Wood, O., West, J., Ottensmeier, C. H., Thomas, G. J. and Hanley, C. J. (2019). An optimised tissue disaggregation and data processing pipeline for characterising fibroblast phenotypes using single-cell RNA sequencing. Sci Rep 9(1): 9580.

31. Witowski, J., Kawka, E., Rudolf, A. and Jorres, A. (2015). New developments in peritoneal fibroblast biology: implications for inflammation and fibrosis in peritoneal dialysis. Biomed Res Int 2015: 134708. 